\title{
Dinamika Resiliensi Ibu Single parent dengan Anak Tuna Ganda
}

\author{
Uswatun Hasanah ${ }^{1} \mathcal{E}$ Sofia Retnowati ${ }^{2}$ \\ Fakultas Psikologi Universitas Gadjah Mada
}

\begin{abstract}
The purpose of this research is to assess the dynamics of resilience on singleparent mother who has a child with double-handicap, starting from the initial phase before and after the diagnosis of double-handicap, stress phase because of the escapement of husband and several risk factors that may arise, up to the phase of adaptation and strengthening. This research used the qualitative method by conducting observation and interview to three informants who domiciled in Kendari. The results showed that there are risk factors which become the initial process in the dynamics of resilience on single-parent mother who has a child with double-handicap, such as family disfunction, financial and social problems, parenting stress on the mother and a belief that mystical factor was causing the problems. Those problems raised negative impacts toward the psychological and physical condition. The attempt made to solve the problems was centered on problem focused coping and emotional focus coping by gaining support from the environment and doing daily activities. The processes of raising and strengthening of resilience on singleparent mother who has a child with double-handicap is also supported by protective factors such as hopefulness, learning from experience, the bond between child and mother, and religious belief.
\end{abstract}

Keywords: dynamics of resilience; single-parent mother who has a child with doublehandicap; qualitative

\begin{abstract}
Abstrak. Penelitian ini bertujuan untuk mengkaji proses dinamika resiliensi ibu single parent dengan anak tuna ganda, dimulai dari fase awal sebelum diagnosis, setelah anak diagnosis tuna ganda, fase stres akibat ditinggal suami, fase adaptasi dan berakhir pada fase penguatan. Penelitian ini menggunakan metode kualitatif dengan melakukan observasi dan wawancara pada tiga orang informan yang berdomisili di Kota Kendari. Hasil penelitian ini menemukan beberapa faktor risiko yang menjadi proses awal dalam dinamika resiliensi seperti disfungsi keluarga, masalah finansial, masalah sosial, stres pengasuhan pada ibu, dan keyakinan terhadap hal mistis. Permasalahan yang dialami menimbulkan dampak negatif pada kondisi fisik dan psikologis. Problem focused coping dan emotional focus coping, digunakan untuk mengatasi permasalahan tersebut, serta memperoleh dukungan dari lingkungan. Proses bangkit dan penguatan resiliensi pada ibu single parent dengan anak tuna ganda didukung adanya faktor protektif seperti memiliki harapan, belajar dari pengalaman, kelekatan yang terjalin antara anak dan ibu, dan keyakinan religius.
\end{abstract}

Kata kunci: dinamika resiliensi; kualitatif; ibu single parent dengan anak tuna ganda

\footnotetext{
${ }^{1}$ Korespondensi mengenai isi artikel ini dapat dilakukan melalui uswatunhasanah17@mail.ugm.ac.id

2 Atau melalui sofi 53@ugm.ac.id
} 
Momen kelahiran menjadi salah satu yang dinantikan dalam pernikahan. Status sebagai pasangan suami-isteri tidak akan lengkap tanpa kehadiran anak. Kenyataan yang terjadi, tidak semua anak dilahirkan dengan kondisi normal, tidak sedikit merupakan Anak Berkebutuhan Khusus (ABK). Hasil Survey dari WHO (InfoDatin, 2014) menemukan bahwa sepertiga dari total penyandang disabilitas dunia, adalah anak-anak berkebutuhan khusus. Jika menggunakan asumsi Persatuan BangsaBangsa (PBB), jumlah ABK di Indonesia diperkirakan kurang lebih 4,2 juta, atau paling sedikit $10 \%$ anak usia sekolah 5-14 tahun (Republika, 2016). Data tersebut menunjukkan terjadi pening-katan secara signifikan jumlah $\mathrm{ABK}$ dan penyandang disabilitas yang tersebar di dunia dan di Indonesia. Kondisi ini menjadi keprihatinan pemerintah, masya-rakat dan menjadi beban tersendiri bagi orang tua yang memiliki ABK.

ABK memiliki hambatan dan keterbatasan dalam menjalani masa tumbuh kembangnya. Hambatan-hambatan tersebut terjadi akibat dari disfungsi pada masa prenatal hingga masa postnatal. Kirk, et al. (2009) mengkategorikan perbedaan dan hambatan ABK ini menjadi, perbedaan intelektual (seperti; gifted, slow learner), cara berkomunikasi (seperti; kesulitan belajar, tunarungu, atau autisme), gangguan mental dan perilaku (seperti; tunalaras, tunagrahita, hiperaktif), fungsi pengindraan (seperti; tunanetra dan tunarungu), kondisi fisik (seperti; tunadaksa) dan ketidakmampuan atau kelainan ganda lainnya (seperti tunaganda, contohnya cerebral palsy dan retardasi mental, atau tunarungu dan tunanetra). Mangungsong (1998) menjelaskan anak dengan tuna ganda adalah anak yang menderita dua atau lebih kelainan dalam segi jasmani, keindraan, mental, sosial, dan emosi, sehingga untuk mencapai perkembangan kemampuan yang optimal diperlukan pelayanan secara khusus dalam pendidikan, medis, dan sebagainya. Anak tunaganda dengan kombinasi kelainan ganda ini memiliki keterbatasan yang lebih berat, karena tidak hanya menganggu satu fungsi tumbuh kembangnya melainkan lebih dari satu.

Keterbatasan tersebut tidak hanya menyulitkan anak dalam masa tumbuh kembangnya tapi juga menyulitkan orangorang yang mengasuh. Orang tua dalam hal ini harus merelakan sebagian besar waktu untuk menghadapi, mengurus, dan merawat anak tunaganda. Kondisi ini dapat menyebabkan stres bagi orang tua sebagai pengasuh. Mangungsong (2011) menyatakan bahwa stres yang dialami orang tua sebagai konsekuensi dari tanggung jawab sehari-hari yang berhubungan dengan perawatan anak dan keberlanjutan masa depan anak. Kondisi tersebut terkait stres yang dialami orang tua dapat menyebabkan terjadinya parenting stress.

Parenting stress atau stres pengasuhan merupakan stres yang dialami orang tua dalam proses pengasuhan, yang berkaitan dengan cara mengatasi perilaku dan berkomunikasi dengan anak (sosialisasi, pengajaran), perawatan atau pengasuhan (mengasuh, melindungi), mencari penyembuhan bagi anak, serta pengaruh stres tersebut terhadap kehidupan pribadi dan keluarga (Phetrasuwan, et al. dalam Auliya et al., 2014). Stres pengasuhan yang dialami orang tua dengan anak tunaganda menjadi sebuah keadaan yang sangat menekan bagi orang tua, sehingga memengaruhi kualitas pengasuhan orang tua pada anak.

Ketika orang tua mengetahui bahwa anaknya didiagnosis menderita tunaganda, kebanyakan merasa tertekan, yang akan memengaruhi kondisi fisik dan psikisnya. Mereka kebingungan karena kurang informasi tentang tunaganda, mimpi dan harapan pupus, mengingkari kenyataan, kecewa atas kondisi anaknya, merasa bersalah, kecemasan, bahkan sebagian dari 
mereka mengalami depresi berat (Kirk, et al., 2009). Hal ini terungkap dari wawancara pada tanggal 27 Maret 2017 kepada salah satu ibu yang anaknya mengalami tunaganda:

"Perasaanku sedih sekali sebagai orang tua serasa sa tidak percaya nda mungkin rasanya na semua anakku normal semua ji barupi dia ini yang begini. Saya kaget lebih-lebih bicaranya keluarga bikin sedih bikin hancur perasaanku, saya juga disalah-salahkan sama keluarga karna anakku begini, bahkan anakku dibilangi orang gila" (SS, 2017).

Berbagai kondisi menekan yang harus ditanggung orang tua dari anak tunaganda merupakan stressor yang dapat memicu ketidakharmonisan suami isteri, bahkan banyak pasangan suami isteri yang bercerai (Ball, 2002). Penelitian Pollet (2010) yang dirilis di New York Law Journal menemukan 5,97\% pasangan suami isteri bercerai karena anaknya berkebutuhan khusus (ABK). Pada keluarga dengan anak autism diperkirakan perceraian mencapai 80-90\%. Kondisi tersebut disebabkan karena ketidakmampuan salah satu pasangan ataupun kedua orang tua dalam mengelola stress berkepanjangan karena anaknya mengalami tuna ganda. Stres yang muncul berupa kekhawatiran tentang masa depan anak, rasa tidak berdaya, hambatan ekonomi, dan kurangnya waktu untuk diri sendiri, (Sutadi, 2003 dalam Ariwibowo, 2015). Dampak dari perceraian orang tua, tidak hanya dirasakan oleh isteri/ibu yang menjadi orang tua tunggal dan memiliki peran ganda, juga dirasakan langsung oleh anak yang berkebutuhan khusus (ABK).

Kehilangan suami karena perceraian dapat menjadi salah satu momen hidup yang menyedihkan khususnya bagi para ibu yang memiliki anak tuna ganda. Kulsum (2013) menyatakan ibu sebagai pengasuh utama anak, merasa bertanggung jawab atas kondisi anaknya, merasa E-JURNAL GAMA JOP lebih sensitif dan rapuh atas apa yang terjadi pada anaknya. Seorang ibu yang menjadi single parent dan mempunyai anak ABK rentan mengalami permasalahan fisik dan psikis (Mangungsong, 1998). Levine (2006) menyatakan di bandingkan dengan ibu yang masih memiliki pasangan, ibu single parent dari $\mathrm{ABK}$ lebih rentan terhadap depresi, disebabkan kekhawatirannya erhadap masa depan anaknya, risiko pengabaian karena kesibukan, kurangnya waktu pelayanan kepada anak tersebut. Ibu single parent dengan anak $\mathrm{ABK}$, memiliki tugas sebagai ibu juga sebagai ayah, yang tentunya penuh dengan tekanan. Bagaimana ibu single parent dengan anak $\mathrm{ABK}$, mampu mengatasi tekanan tersebut dan kemudian bisa bangkit untuk menjalankan kehidupannya secara normal?

Strandova (2006) menyebutkan ada beberapa tahap yang dilalui oleh ibu single parent dengan $\mathrm{ABK}$ untuk mencoba koping dan menerima kenyataan bahwa anaknya mengalami disabilitas; tahap pertama adalah orang tua mengalami shock dan menolak diagnosa yang diberikan, tahap kedua orang tua secara bertahap akan menerima kenyataan dan mencoba koping terhadap permasalahan tersebut, dan terakhir tahap realistic attitude. Keberhasilan akan diperoleh seorang ibu single parent jika dapat melalui tahapan-tahapan tersebut hingga akhirnya mampu menyesuaikan diri dan beradaptasi terhadap keadaan menekan.

Agar bisa beradaptasi dengan baik, ibu single parent harus bisa menggunakan sumber daya yang dimilikinya, seperti sumber daya internal (ketahanan, adaptasi positif, penerimaan dan penyesuaian diri) dan sumber daya eksternal (dukungan sosial dan kondisi sosial ekonomi). Apostelina (2012) menyebutkan sumber daya tersebut dapat berupa dukungan sosial yang diperoleh dari keluarga, kerabat, teman, tetangga, serta komunitas 
dan sumber daya sistem keluarga yang meliputi kemampuan ketahanan keluarga (resiliensi). Ibu single parent dengan tunaganda yang mampu mengoptimalkan sumber dayanya dan melakukan adaptasi dengan baik akan mencapai keseimbangan didalam keluarga, ibu tersebut dikatakan resilien. Reivich \& Shatte (2002) menyebutkan bahwa resiliensi merupakan kapasitas individu untuk berespon secara sehat dan produktif ketika dihadapkan dengan kesengsaraan atau trauma. Individu yang resilien bukan berarti tidak mengalami masalah, tetapi mampu bangkit dan terus bertahan dari situasi menekan atau keterpurukan yang menimpa dirinya.

Arsiani (2009) menyatakan ibu single parent dengan ABK yang memiliki kemampuan dalam mengembangkan dan mengoptimalkan kemampuan resiliensinya, akan lebih mudah bangkit dan beradaptasi dari permasalahan yang dihadapinya sehari-hari. Kemampuan resiliensi yang di miliki ibu tersebut membuat sang ibu dapat memanfaatkan kekuatan yang ada dalam dirinya untuk membantu menjalankan peran ganda dan mengasuh anak tuna-ganda. Pencapaian resiliensi Ibu single parent dengan anak tuna ganda apabila akan ditandai dengan memiliki pandangan positif dan harapan yang baik terutama mengenai masa depan buahhati mereka. Berdasarkan hasil wawancara pendahuluan terhadap ibu single parent dengan anak tunaganda mengungkapkan:

"Mau bagaimanapun kondisi hidup sekarang dan kondisinya anakku namanya juga anak sendiri to mau tidak mau harus kita asuh selama kita masih ada di dunia ya kita urus saja karena kalo kita tidak ada mi di dunia siapa mi yang urus. Saya yakin anakku punya kelebihan yang bisa kasih sukses dia dimasa depan. Saya juga selalu tanamkan didalam diriku Allah dia titipkan saya anak ini karena saya orang terpilih orang kuat dan saya diperaya bisa asuh dan besarkan dia sendiri walaupun saya sendiri yang hidupi tapi masih ada saya punya mama yang bantu saya" (MA, 2017)

Pencapaian resiliensi merupakan salah satu hal yang tidak mudah diterapkan didalam kehidupan karena besarnya beban yang harus di hadapi. Permasalahan yang begitu kompleks yang dihadapi ibu single parent dengan anak tunaganda merupakan masalah yang melibatkan beban sosial, psikis, dan dapat menimbulkan penyakit fisiologis. Peneliti dalam hal ini ingin mengetahui proses dan faktor-faktor pencapaian resiliensi pada ibu single parent dalam mengasuh dan membesarkan anak dengan tunaganda. Dengan demikian, peneliti dapat mengetahui lebih dalam tentang dinamika resiliensi pada ibu single parent yang memiliki dengan anak tunaganda.

\section{Metode}

\section{Subjek}

Subjek dalam penelitian ini adalah tiga orang ibu single parent yang disebabkan karena perceraian, baik cerai hidup maupun cerai mati dan yang memiliki anak dengan diagnosis tuna ganda. Ketiga subjek berdomisili di Kota Kendari Provinsi Sulawesi Tenggara. Subjek pertama disebabkan karena cerai hidup dan memiliki anak dengan diagnosis autism-tuna rungu, subjek kedua juga disebabkan karena cerai hidup dan memiliki anak dengan diagnosis down syndrome-autism, dan subjek ketiga adalah ibu single parent karena cerai mati dan memiliki anak dengan diagnosis down syndrome-tuna rungu.

\section{Cara pengumpulan data}

Penelitian ini menggunakan pendekatan kualitatif dengan model penelitian yang 
studi kasus. Peneliti dalam penelitian ini merupakan instrumen utama dan mencoba mengumpulkan sendiri data penelitian dengan wawancara dan observasi serta bantuan recorder handphone sebagai teknik pengumpulan data pelengkap. Wawancara yang digunakan adalah wawancara mendalam (in-depth interview). Pelaksanaan penelitian ini dimulai pada tanggal 7 April 2017 hingga 3 Juli 2017.

\section{Analisis data}

Analisis data pada penelitian ini menggunakan analisis tematik yang didahului dengan pengumpulan data, pengorganisasian data, dikelompokkan berdasarkan tema, dilakukannya analisis dan interpretasi data. Dari hal-hal tersebut kemudian dapat ditemukan tema dan dapat dilakukan analisis tematik.

\section{Hasil}

Fase awal, yang dialami dari ketiga informan, melihat adanya keganjilan pada perkembangan anak dan menerima diagnosis bahwa anaknya mengalami tuna ganda. Tekanan mulai dirasakan setelah suami informan tidak memberi dukungan. Perubahan pola pengasuhan yang dialami orang tua dengan anak tuna ganda disebabkan karena ketidakmampuan atau adanya ketidaksepahaman antara ibu dan anak dalam membaca isyarat yang diberi anak sehingga anak mengungkapkannya dengan merusak dan melakukan tindakan agresif lainnya. Perbedaan pola pengasuhan tersebut menjadi tekanan tersendiri yang dialami ibu sebelum dan sesudah menerima diagnosis tuna ganda pada anak. Fase kedua adalah fase stres yang disebabkan karena perceraian informan dengan suami dan diperkuat dengan faktor risiko seperti disfungsi keluarga, stres pengasuhan, masalah finansial, masalah lingkungan tempat tinggal seperti anak

E-JURNAL GAMA JOP mendapat bullying dari masyarakat sekitar, kebimbangan terhadap masa depan anak dan keyakinan bahwa anaknya mendapat guna-guna, sehingga memengaruhi kondisi fisik dan psikologis informan. Informan pertama dan kedua mengalami gangguan kesehatan fisik dan informan kedua mengalami trauma ketika akan melahirkan anak keduanya, informan merasa takut apabila anak tuna ganda lagi.

Fase ketiga adalah fase adaptasi dan bangkit, yakni pengelolaan stres yang dilakukan oleh ketiga informan dengan menerima dukungan dari orang lain seperti anak, keluarga, tetangga dan terutama dukungan dari kelompok pertemanan sesama orang tua dengan anak berkebutuhan khusus. Melakukan aktivitas positif seperti ikut komunitas spiritual dan berdagang, kemudian ketiga informan mencoba mengabaikan masalah mampu menjadi cara dalam penanganan stres.

Sebelum mencapai karakteristik resilien, ketiga informan dikuatkan dengan beberapa hal yang menjadi faktor protektif, antara lain harapan yang realistik, belajar dari pengalaman, dan kelekatan antara orang tua dengan anaknya. Dalam hal ini ibu sebagai orang tua tunggal menjadikan anak sebagai satu-satunya harapan dan semangat hidup untuk menjalani hidup dengan lebih positif dan penuh makna. Religious belief menjadi penguat dan merupakan keyakinan yang telah dimiliki informan sebelum hingga setelah terjadinya permasalahan. Keyakinan tersebut menjadi kekuatan tersendiri untuk tetap bertahan dalam menghadapi cobaan yang telah dititipkan Tuhan, ketiga informan meningkatkan religiusitas dengan melakukan rutinitas seperti berdoa dan shalat.

Fase terakhir, ketiga informan mencapai karakteristik resiliensi yang bersumber dari aspek internal informan dan aspek eksternal informan. Adapun karakteristik resiliensi yang bersumber dari aspek internal diri informan adalah oto- 
nomi yang terdiri dari aspek identitas positif, internal locus of control, penyesuaian diri, self awareness dan juga humor. Karakteristik resiliensi yang bersumber dari aspek eksternal diri informan adalah kompetensi sosial yang terdiri dari aspek komunikasi, empati, dan compassion altruism forgiveness serta problem solving yang terdiri dari aspek fleksibilitas, banyak sumber akal, kemampuan berpikir kritis, kesadaran tujuan masa depan. Tercapainya karakteristik individu yang resilien menjadi tahapan akhir dalam fase penguatan dinamika ibu single parent dengan anak tuna ganda. Resiliensi bukanlah hasil akhir dari sebuah pencapaian, namun resiliensi merupakan modal adaptasi positif bagi individu ketika akan menghadapi permasa-lahan yang menekan dan menjadi karakter penguat individu untuk lebih cepat bangkit dari permasalahan.

\section{Diskusi}

Mengasuh dan membesarkan anak tuna ganda menjadi stressor tersendiri dalam kehidupan seorang ibu. Pola interaksi yang terjalin antara ibu dan anak tuna ganda juga berbeda dengan anak pada umumnya. Ibu single parent harus mendidik anaknya lebih kuat agar anak bisa mandiri seperti makan, buang air besar dan kecil, mandi, dan mengganti pakaian. Hasil wawancara yang diperoleh bahwa dua dari tiga informan lebih mudah menerima keadaan anak yang mengalami tuna ganda karena masih memperoleh dukungan dari suami, dari hasil ini dapat dilihat bahwa penerimaan akan mudah dilakukan oleh ibu apabila mendapat dukungan dari pasangan dibandingkan tidak mendapat dukungan dari pasangan. Tidak hanya itu, ketiga informan harus menerima Kenyataan pahit karena ditinggal pergi karena perceraian ilegal dan karena kematian suaminya. Cohen dan Bolton (1993) mengatakan bahwa memiliki anak berkebutuhan khusus dapat menyebabkan stres serta sangat memengaruhi suatu hubungan pernikahan. Hubungan pernikahan tersebut dapat mengalami keretakan seperti perpisahan dan perceraian dibandingkan orang tua yang memiliki anak normal. Ketiga informan harus menanggung beban pengasuhan seorang diri tanpa pendampingan suami dan keluarga dari pihak suami. Dua dari tiga informan ditinggal pergi oleh suami (minggat) setelah mengetahui diagnosis dan merasakan beban pengasuhan anak tuna ganda dan memilih untuk memulai hidup baru dengan wanita lain. Akibat kepergian suami pada ibu dengan anak tuna ganda menimbulkan beberapa faktor risiko seperti disfungsi keluarga, masalah finansial, dan kebimbangan mengenai masa depan anaknya.

Akibat perbedaan pola interaksi orang tua dengan anak tuna ganda dengan anak pada umumnya ibu single parent dengan anak tuna ganda rentan mengalami stres pengasuhan, anak tuna ganda kerap tak mampu mengungkapkan keinginannya dan isyarat yang diberikan kepada ibu tidak dapat diinterpretasikan oleh ibu sehingga menimbulkan perilaku merusak barang pada anak, tantrum, membanting barang, hingga perilaku anak tuna ganda yang memukuli ibu. Kebimbangan menghadapi masa depan anak tuna ganda menjadi salah satu faktor risiko dan menimbulkan kecemasan pada ibu terhadap masa depan anaknya. Ketiga informan kerap mengkhawatirkan pengasuh anaknya yang mengalami tuna ganda ketika ketiga informan telah meninggal dunia. Minimnya sarana dan prasarana yang ada di Kota Kendari dalam rangka mewadahi dan memberikan edukasi kepada ibu dengan anak berkebutuhan khusus untuk membekali anaknya keterampilan guna keterampilan yang dimiliki anak bisa menjadi modal dalam menyongsong masa

E-JURNAL GAMA JOP 
depan mandiri. Kondisi tersebut didukung dengan paparan teori dari Monty (2006) juga dapat mendukung hasil penelitian ini, yang menyebutkan, stres dapat dialami oleh setiap individu dalam kehidupan sehari-hari akan tetapi, stres mengasuh khususnya dalam pengasuhan anak memiliki kekhasan tersendiri atau keadaan yang tidak pada umumnya. Kekhasan tersebut meliputi; kondisi anak (termasuk perilaku anak yang menyimpang), kondisi kehidupan menyeluruh yang menimbulkan stres, tidak mendapat dukungan sosial, fungsi keluarga, dan sumber material seperti mencakup fasilitas hidup, termasuk sandang, pangan, dan papan.

Dalam penelitian ini, ketiga informan meyakini adanya hal mistis sebagai pemicu munculnya permasalahan dalam hidupnya. Mereka mempercayai bahwa penyebab perselingkuhan suami dan anak yang terdiagnosis tuna ganda karena adanya guna-guna. Simuh (Anisah, 2012) menjelaskan bahwa kepercayaan terhadap rohroh dan tenaga gaib yang meresapi seluruh kehidupan baik individu maupun antar masyarakat secara keseluruhan. Pikiran dan perbuatan tertuju bagaimana mendapat bantuan ruh baik dan menjauhkan pengaruh roh yang mengganggu atau menghalangi. Kepercayaan terhadap hal mistis juga menjadi strategi ibu single parent untuk melakukan penyangkalan dan me-rasionalisasikan permasalahan yang terjadi dengan mengasumsikan bahwa hal mistislah sebagai pemicu penyebab perselingkuhan suami dan penyebab anaknya mengalami tuna ganda. Keyakinan mengenai hal mistis ini juga dapat menjadi strategi koping pada ibu, karena ibu tidak menyalahkan dirinya atas permasalahan yang terjadi, namun kondisi yang dialami ibu saat ini disebabkan karena pengaruh hal mistis.

Hal yang dapat diungkap juga dalam penelitian ini adalah hingga saat ini ketiE-JURNAL GAMA JOP dakadilan gender masih terjadi yang memarginalkan kaum perempuan, dalam hal ini ibu. Perbedaan gender melahirkan ketidakadilan gender dalam hal ini perempuan dan laki-laki memilki peran berdasar label atau konstruksi sosial yang telah diberi masyarakat atau budaya yang berlaku di suatu daerah. Fakih (1996) mengungkapkan bahwa konstruksi sosial gender kaum laki-laki harus bersifat kuat, agresif, dan memiliki peran gender untuk tidak melakukan tugas domestik, sebaliknya dengan perempuan memiliki peran gender dalam mendidik anak, mengasuh, merawat, mengelola kebersihan rumah, yang kemudian menjadi "kodrat wanita" dalam konstruksi sosial atau gender terkukuhkan menjadi "kodrat kultural".

Pernyataan Fakih (1996) tersebut sejalan dengan apa yang ditunjukkan pada hasil penelitian ini bahwa marginalisasi terhadap kaum perempuan sudah terjadi sejak di rumah tangga dalam bentuk diskriminasi anggota keluarga. Beban dan tanggung jawab pengasuhan yang telah menjadi kodrat kultural ataupun kodrat wanita dengan begitu setiap permasalahan ataupun hambatan yang terjadi pada anak seperti anak mengalami tuna ganda lakilaki dalam hal ini ayah melepas tanggung jawab dan membebani perempuan dalam hal ini ibu untuk bertanggung jawab sepenuhnya terhadap kondisi anak. Ibu dan ayah dalam hal ini memiliki tanggung jawab yang sama dalam hal pengasuhan dan perawatan anak, apapun kondisi dan keadaan yang dialami anak orang tua baik ibu maupun ayah harus bekerja sama untuk terus membantu anak mencapai perkem-bangan yang lebih optimal.

Beban pengasuhan dan konstruksi gender mengisyaratkan bahwa perempuan dengan sifat lemah lembut mampu mengerjakan pekerjaan domestik. Ini menyebabkan perempuan memiliki tanggung jawab penuh dalam pengasuhan anak sedangkan laki-laki sejak dini telah 
disosialisasikan untuk menekuni peran gender mereka. Kondisi tersebut memperkuat pelanggengan atau konstruksi sosial yang telah terbangun tersebut mengenai beban pengasuhan anak sepenuhnya menjadi tanggung jawab ibu atau perempuan. Tidak dapat dipungkiri bahwa ibu adalah pengasuh utama karena tugas tunggalnya dalam melahirkan dan menyusui tidak dapat digantikan oleh lakilaki namun tugas pengasuhan adalah tanggung jawab bersama bukan hanya tanggung jawab ibu.

Dukungan yang sangat memengaruhi motivasi hidup dan pencapaian resiliensi ibu single parent dengan anak tuna ganda adalah dengan memperoleh dukungan dari sesama orang tua yang memiliki anak berkebutuhan khusus. Ketiga informan memiliki kelompok khusus yang dapat berfungsi sebagai "kelompok penolong" orang tua dengan anak berkebutuhan khusus. Melalui kelompok ini, informan mendapatkan banyak dukungan tidak hanya dukungan moril seperti berbagi kisah dan berbagi permasalahan beserta solusinya dan juga dukungan materi, dalam penelitian ini ditemukan bahwa ketiga informan mendapatkan lebih banyak dukungan baik emosi maupun materi dari kelompok penolong ini dibandingkan dari keluarga dekat atau tetangga. Ditemukan juga dalam penelitian ini, ibu single parent dengan anak tuna ganda merasakan kenyamanan, kepuasan dan keterbukaan ketika bercerita atau berbagi mengenai kehidupan sehari-hari mengenai masalah pengasuhan anak tuna ganda dan masalah rumah tangganya kepada orang tua yang juga memiliki anak berkebutuhan khusus dibandingkan dengan orang tua yang tidak memiliki anak berkebutuhan khusus, karena ibu single parent dengan anak tuna ganda meyakini bahwa bercerita dan berbagi kepada sesama orang tua dengan anak berkebutuhan khusus lebih mudah mendapatkan penyelesaian masa- lah karena mereka menghadapi permasalahan yang tidak jauh berbeda. Kemudian, Kenyamanan dalam bercerita akan didapatkan pada sesama orang tua dengan anak berkebutuhan khusus karena tidak akan mendapatkan bullying mengenai kondisi anaknya, masih terdapat stigma negatif dari masyarakat bahwa kehadiran anak berkebutuhan khusus di dalam sebuah keluarga menjadi "aib" atau sesuatu yang memalukan bagi keluarga. Berada dan berkumpul di kelompok kecil seperti kelompok orang tua dengan anak berkebutuhan khusus mampu mendukung percepatan pencapaian resilensi bagi ibu single parent dengan anak tuna ganda, kondisi ini disebabkan karena munculnya solidaritas dari sesama orang tua dengan anak berkebutuhan khusus dan melalui kelompok ini ibu bisa menemukan beragam solusi dari setiap permasalahan yang dihadapi tidak hanya masalah pengasuhan dan rumah tangga juga masalah kehidupan lainnya.

Hal ini sesuai dengan pendapat para ahli yang menggolongkan dua strategi koping yang digunakan oleh individu, yaitu: problem focused coping, dalam hal ini individu secara aktif mencari penyelesaian dari masalah untuk menghilangkan kondisi atau situasi yang menimbulkan stres, dan emotion focused coping, dalam hal ini individu melibatkan usaha-usaha untuk mengatur emosinya dalam rangka menyesuaikan diri dengan dampak yang akan ditimbulkan oleh suatu situasi penuh tekanan (Lazarus dan Folkman, 1984 dalam Sarafino, 1998). Dapat dilihat dari hasil penelitian bahwa ketiga informan menggunakan kedua cara tersebut untuk mengatasi masalah yang dihadapi dalam hidupnya. Bentuk usaha koping pada masalah misalnya mendapat dukungan dari keluarga, anak, kerabat, dan tetangga sekitar tempat tinggal. Selain mendapat dukungan, ketiga informan memfokuskan dirinya untuk berdagang, bekerja dan E-JURNAL GAMA JOP 
mengurus anak. Aktivitas yang dilakukan tersebut dianggap sebagai langkah positif yang mampu mengalihkan perasaan sedih dan tertekan yang disebabkan karena permasalahan yang dihadapi. Stres, rasa sedih, dan kecewa yang dirasakan informan perlahan berkurang seiring usaha mereka dalam memberikan penanganan, pengasuhan serta menunjukkan kemandiriannya dalam memimpin rumah tangga seorang diri.

Ketiga informan juga melakukan usaha yang terfokus pada emosi dalam
Kemudian adaptasi yang dilakukan ketiga informan dengan melalui strategi koping tersebut diperkuat dengan adanya faktor protektif seperti menjadikan anak sebagai motivasi hidup, adanya religious belief sebelum dan setelah masalah terjadi, dan harapan yang realistik mengenai masa depan diri dan anaknya. Tahapan-tahapan tersebut menjadi penguat bagi ketiga informan sebelum mencapai karakteristik resilien. Brooks dalam Lightsey (2006) mendefinisikan resiliensi sebagai kapasitas individu untuk secara efektif menangani

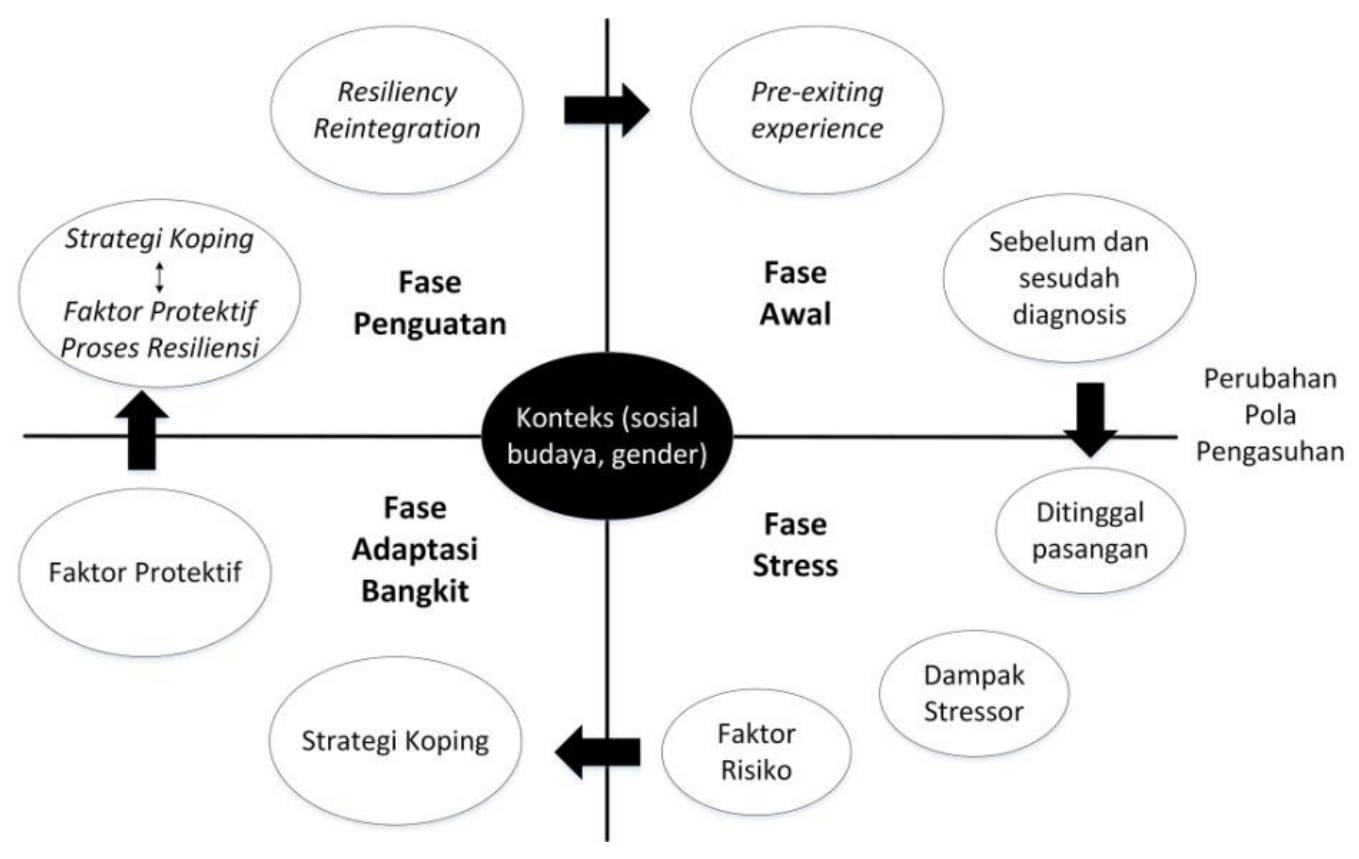

Gambar 1.

Siklus Resiliensi Ibu Single parent dengan Anak Tuna Ganda

dirinya. Kesamaan keterampilan yang ditemukan dari tiga informan seperti, mengabaikan masalah. Informan berusaha untuk mengatur emosi dan tindakan yang berhubungan dengan permasalahan yang timbul dengan mengaitkan kepada hal-hal positif dan hal-hal yang sifatnya religius. Menurut Lawford \& Eiser (2001) faktor yang membedakan tingkat kualitas hidup seseorang pada situasi yang sama adalah cara mengatasi atau koping ketika mengalami kesulitan, yang telah diidentifikasi sebagai fokus dari resiliensi. stres dan tekanan hidup, hal ini juga menjadi kekuatan untuk pulih dari kekecewaan, rasa bersalah yang mendalam, trauma, mampu membantu mengembangkan tujuan hidup yang lebih jelas dan realistis.

Setelah menghadapi paparan permasalahan, ketiga informan menjadi individu yang memiliki kompetensi sosial, kemampuan otonomi yang baik, memiliki kemampuan pemecahan masalah, dan memiliki arah dan tujuan masa depan. Dari pemaparan analisis dan pembahasan 
penelitian ini dapat digambarkan dengan siklus resilensi ibu single parent dengan anak tuna ganda berikut. Dari gambar tersebut terlihat bahwa konteks lingkungan dalam hal ini sosial, budaya, gender, dan sebaginya menempati posisi sentral dengan melihat konteks lingkungan mampu memberi pengaruh pada semua fase yang ada pada siklus resiliensi ibu single parent dengan anak tuna ganda.

\section{Kesimpulan}

Dukungan yang diberikan pada ibu dari kelompok sesama orang tua dengan anak berkebutuhan khusus lebih diterima dan mampu mempercepat pencapaian karakteristik resiliensi ibu dibandingkan dengan dukungan dari sumber lain seperti tetangga, keluarga, dan teman terutama yang tidak pernah mengalami pengalaman mengasuh anak berkebutuhan khusus.

Ketiga informan melakukan rasionalisasi dan penolakan atas kondisi anak yang mengalami tuna ganda dan perceraian dengan suami, dengan keyakinan bahwa hal tersebut disebabkan oleh mistis. Dinamika resiliensi ibu single parent dengan anak tuna ganda merupakan sebuah siklus yang akan terus berulang, seiring berjalannya waktu kekuatan ini semakin dibutuhkan mengingat permasalahan ibu single parent dengan anak tuna ganda akan semakin bertambah.

\section{Saran}

Berdasarkan temuan yang didapatkan dalam penelitian yang telah dilakukan, peneliti dapat memberikan saran kepada bagi Ibu single parent yang memiliki anak tuna ganda untuk terus meningkatkan resiliensi yang dimiliki. Serta mampu menjadi model bagi orang tua atau ibu single parent yang memiliki anak tuna ganda agar mampu beradaptasi dan bertahan dalam mengasuh anak tuna ganda.
Saran bagi peneliti selanjutnya, dalam penelitian ini peneliti masih sulit mengungkapkan mengenai faktor risiko sebagai pemicu stres ibu yaitu keyakinan terhadap hal mistis sebagai penyebab permasalahan. Peneliti belum mampu mengkaji lebih dalam, dan diharapkan adanya studi lebih lanjut yang mengkaji mengenai faktor tersebut. Serta dapat menggali informasi dari significant others dengan harapan dapat memperkuat tingkat kepercayaan data dan menambah khazanah data sehingga peneliti selanjutnya mampu mengeksplorasi dinamika resiliensi ibu single parent dengan anak tuna ganda lebih mendalam.

\section{Daftar Pustaka}

Apostelina, E. (2012). Resiliensi keluarga pada keluarga yang memiliki anak autis. Jurnal Penelitian dan Pengukuran Psikologi 1(1), 164-176.

Arsiani, A. (2009). Gambaran resiliensi ibu yang memiliki anak autistik. (Tesis tidak dipublikasikan). Fakultas Psikologi Universitas Indonesia, Depok.

Ariwibowo, V. (2015). Resiliensi ibu dengan anak autis. (Tesis tidak dipublikasikan) Fakultas Psikologi Unveristas Gadjah Mada.

Auliya, I. A., \& Darmawanti, I. (2014). Hubungan antara kepribadian hardiness dengan stres pengasuhan pada ibu yang memiliki anak cerebralpalsy. Jurnal Character Universitas Negri Surabaya (UNESA), 3(02), 02.

Anisah, F. (2012). Pengaruh perilaku budaya dinamisme terhadap kualitas keimanan masyarakat desa Mlilir, Semarang. (Skripsi dipublikasikan). Fakultas Pendidikan Agama Islam Sekolah Tinggi Agama Islam Salatiga. 
http://perpus.iainsalatiga.ac.id/docfil es/fulltext/f483bcdae00bee5b.pdf.

Ball, S. (2002). Children with special needs in divorce. Domestic Relations Program Manager. CASA of Colorado Springs, CO 80903 USA. Page: 2.

Cohen, B. S., \& Bolton, P. (1993). Autism: The facts. New York: Oxford University Press.

Fakih, M. (1996). Analisis gender dan transformasi sosial. Yogyakarta: Pustaka Pelajar.

InfoDatin. (2014). Penyandang disabilitas pada anak: Peringatan 3 Desember hari penyandang cacat sedunia. Pusat Data dan Informasi Kementrian Kesehatan RI.

Kulsum, Ummi. (2013). Faktor resiliensi pada ibu dengan anak penyandang tuna rungu. (Skripsi tidak dipubikasikan). Fakultas Psikologi Universitas Brawijaya.

Kirk, S., Gallagher, J. J., Coleman, M. R., \& Anastasiow, N. J. (2009). Educating exceptional children 12th edition. Boston, USA: Houghton Miffl in Harcourt Publishing Company.

Levine, K., Kathryn. (2006). Against all odds: Resilience in single mothers of childrend with disabiliies. Dissertation Faculty of Social Work University of Manitoba. Winnipeg, Canada.

Lightsey, O. R. (2006). Resilience, meaning and well being. The Counseling Psychologist, (34), 96-107. doi: 10.1177/ 0011000005282369? journalCode=tcpa

Lawford, J., \& Eiser, C. (2001). Exploring links between the concept of quality of life and resilience. Journal of
Pediatric Rehabilitation, 4, 209-216. doi: 10.1080/13638490210124024

Mangungsong, F. (1998). Psikologi dan pendidikan anak luar biasa. Depok: Lembaga Sarana Pengukuran dan Pendidikan Psikologi Universitas Indonesia.

Mangunsong, F. (2009). Psikologi dan pendidikan anak berkebutuhan khusus, jilid satu. Depok: Lembaga Sarana Pengukuran dan Pendidikan Psikologi Universitas Indonesia.

Mangungsong, F. (2011). Psikologi pendidikan anak berkebutuhan khusus, Jilid Kedua. Depok: Lembaga Sarana Pengukuran dan Pendidikan Psikologi Universitas Indonesia.

Monty, P. S. (2006). Bunga rampai psikologi perkembangan: Dari anak sampai usia lanjut cetakan 2. Disunting oleh Gunarsa, Singgih D. Jakarta: BPK Gunung Mulia.

Pollet, S. L. (2010). Impact of separation or divorce on special needs children. New York Law Journal, 4(1), 244.

Reivich, K \& Shatte, A. (2002). The resilience factor: 7 skills for overcoming life's inevitable obstacles. New York: Random Hause, Inc.

Sarafino, E. P. (1998). Health psychology biopsycological interaction. New York: Jhon Willey \& sons, Inc.

Strandova, I. (2006). Stressand resilience in families of children with specific learning disabilities. Rev. Compult Education. 17(2), 35-50.

Situs online:

www.republika.co.id diakses pada 5 Maret 2016 pukul 19.40 WIB 